\title{
Chilean benthic species identified as a new source of antibiotic substances
}

\author{
Erwin Strahsburger ${ }^{1,2}$, Jessica Pizarro ${ }^{1}$, Alex Zúñiga ${ }^{1}$, Sergio Ocares ${ }^{1}$ \\ Camila Vallejos $^{1} \&$ Michael McClelland ${ }^{2}$ \\ ${ }^{1}$ Faculty of Renewable Natural Resources, Arturo Prat University, Iquique, Tarapacá, Chile \\ ${ }^{2}$ Department of Microbiology and Molecular Genetics, University of California Irvine \\ Irvine, CA, United States \\ Corresponding author: Erwin Strahsburger (estrahsb@unap.cl)
}

\begin{abstract}
Benthic marine organisms are a natural source of bioactive substances with applications in medicine to treat infections, cancer and other diseases. In Chile, this community possesses rich biodiversity that has been scarcely studied as a producer of bioactive substance so far. For that reason, we studied the potential production of antibiotic substances in 28 benthic species that inhabit the coast of the Tarapacá region in northern Chile, and belong to phylum Porifera, Cnidaria, Mollusca, Sipuncula, Annelida, Echinodermata and Chordata. The antibiotic activity was evaluated on ethanol extract obtained from their entire body or dissected tissues and was tested against Staphylococcus aureus ATCC 25923 with the diffusion agar method. According to the halo diameter, the antibiotic potency was classified as mild, regular or high. In this way, we could identify 21 benthic species as a producer of antibiotic substances with different antibiotic potency. This activity was found in more than one tissue and with regular or high antibiotic activity in the species; Acanthopleura echinata, Chiton cumingsii, Aulacomya atra, Fissurella crassa, Fissurella latimarginata, Luidia magellanica, Stichaster striatus, Arbacia spatuligera, and Loxechinus albus. The extracts obtained from the entire body and showed regular and high antibiotic activity were from the species; Phymanthea pluvia, Abarenicola affinis, Glycera americana, and Ophiactis kroyeri. In conclusion, northern Chile possesses a rich biodiversity of benthic species producer of antibiotic substances, and more research is encouraged to identify these substances with application in medicine.
\end{abstract}

Keywords: Staphylococcus aureus; antimicrobial; organic extract; benthos; northern Chile

\section{INTRODUCTION}

The benthic community comprises all organisms living at the sea bottom. Some of them, such as sea urchins, crabs and mollusks are considered an exquisite seafood, while others, such as algae, sponges, holothurians and others are considered a natural source of bioactive compounds with application in medicine (Berlinck et al., 2004; Laport et al., 2009; Suleria et al., 2015; Nalini et al., 2018; Puglisi et al., 2019). In fact, in ancient traditional medicine, diverse beverage to treat diseases like colds, sore throats, chest infections and tuberculosis were formulated using raw benthic organisms as the main ingredient (Dias et al., 2012; Suleria et al., 2015; Nalini et al., 2018; Prakash et al., 2018). To date, benthic species are considered a good source of bioactive compounds and many studies are identifying new antibiotic substances from them
(Wagenlehner et al., 2016; Sana et al., 2017; El Chakhtoura et al., 2018; Ogawa et al., 2018; Campos et al., 2019; Isler et al., 2019).

Chilean marine ecosystem is one of the most productive in the world and comprises diverse benthonic species along its coast. This rich biodiversity is due to the presence of different marine currents and environment conditions that harbors a rich trophic chain (Gallardo, et al., 1995; Castilla \& Fernandez, 1998; Escribano et al., 2003; Lee et al., 2008; Betti et al., 2017; Aguilera et al., 2019). However, this richness is contrasted with the few studies about its application as a natural source of bioactive substances. In Valparaiso Bay at central Chile, the southern region and the Antarctica continent, many studies have identified bacteria, algae and benthic organisms as a new source of bioactive compounds with potential application as a news antibiotics, antivirals or antitumoral drugs

Corresponding editor: Paulo Paiva 
(Henriquez et al., 1979; Hayashida-Soiza et al., 2008; Jiménez et al., 2011; Sottorff et al., 2013; Claverías et al., 2015; Arnau et al., 2016; Undabarrena et al., 2016).

On the other hand, in northern Chile, only two studies have described bioactive compounds in benthic organisms. One identifies four seaweeds species as the producer of secondary metabolites that protect them from mussel's attachment (Pansch et al., 2009). Meanwhile, the other study describes a fungus isolated from the marine sponge Cliona chilensis, with the ability to produce antimicrobial and antitumor compounds (San-Martin et al., 2011). Therefore, the present report aims to increase the knowledge about Chilean benthic marine organisms as a natural source of bioactive compounds, especially in northern Chile. The organic ethanol extract obtained from 28 marine species living along the coast of the Tarapacá region was analyzed on a loan of Staphylococcus aureus ATCC 25923. The antibiotic activity observed in many species encourages doing more studies on Chilean benthic organisms as a natural source of bioactive substances with application in medicine.

\section{MATERIALS \& METHODS}

\section{Collection of benthic organisms}

In this study, we included 28 benthic species collected from the intertidal and subtidal zone of coast of Tarapacá region (ca. 0-18 m depth), northern Chile (20$21^{\circ} \mathrm{S}$ ) (Table 1). Among 5-10 individuals per each species were collected, preserved in marine water, and transported to the aquaculture facilities of the Faculty of Renewable Natural Resources of Arturo Prat University, Iquique City, Chile. They were maintained in starvation for $24 \mathrm{~h}$ in artificial ponds protected from the direct sun exposition and under continuous current of filtered fresh marine water.

\section{Specimen preparation}

The benthic species analyzed as an entire body were from phyla Porifera, Cnidaria, Sipuncula, Annelida, Echinodermata and Chordata. They were mechanically cleaned, removing any superficial particles, washed with tap water, and dried at $65^{\circ} \mathrm{C}$.

Meanwhile, the dissected marine specimens were from the phyla Echinodermata and Molusca. The entire body was first washed with tap water and then dissected. The specimens of class Asteroidea were dissected in the stomach, ambulacral feet, blind pyloric, gonads, central dermoskeleton and arm dermoskeleton. The specimens of class Echinoidea were dissected in Aristotle's lantern, intestine, spines and gonads differentiated between male and female. Mollusks were dissected in diverse organs according to the species. In general, were obtained the periesophageal ring, foot, radulae, ctenidia, retractor muscles, digestive glandintestine, mantle, lamellas and gonads, differentiated between male and female. All dissected organs and structures were immediately dried at $65^{\circ} \mathrm{C}$.

\section{Ethanol extraction}

Each dried sample was ground until obtaining a fine powder and mixed with three volumes of $100 \%$ ethanol (Merck-Schuchardt, Germany). The mixture was incubated at $37^{\circ} \mathrm{C}$ in agitation $(150 \mathrm{rpm})$ for $24 \mathrm{~h}$ and finally decanted. The supernatant was filtered with 0.4 $\mu \mathrm{m}$ filters (Fisher Scientific) and incubated at $50^{\circ} \mathrm{C}$ in a dry-bath (Barnstead/Thermolyne Corp) until it reduces its volume 10 times. The concentrated sample was immediately evaluated with an antibacterial assay or stored at $-20^{\circ} \mathrm{C}$ until further analysis.

\section{Antibacterial assay}

The antibacterial assay was performed as described in the literature (Mercado et al., 2008) but with modifications. Briefly, the sensitive bacteria Staphylococcus aureus ATCC 25923 was culture in Luria Bertani (LB) broth (Difco BD) at $37^{\circ} \mathrm{C}$ in aerobic conditions. The culture was stopped when it reached an optical density of 0.7 measured at $600 \mathrm{~nm}$ in a spectrophotometer (Biomate 5, Thermo Fisher Sci). Then, an aliquot of 0.2 $\mathrm{mL}$ was mixed with $5 \mathrm{~mL}$ of melted LB soft agar $(0.7 \%)$, gently mixed and added on the surface of an LB agar plate. After agar solidification (bacterial lawn), a drop of $5 \mu \mathrm{L}$ from each concentrated ethanol extract was added. A drop of $5 \mu \mathrm{L}$ of $100 \%$ ethanol was included as solvent control. The drops were evaporated under sterile conditions, and then, the plate was incubated at $37^{\circ} \mathrm{C}$ for $18-24 \mathrm{~h}$. The presence of a halo was representative of inhibition of growing of $S$. aureus strain. The presence of cloudy halo was registered as a mild antibiotic activity (+), a transparent halo with a diameter $\leq 0.8 \mathrm{~mm}$ was registered as regular antibiotic activity (++), and with diameters $>0.8 \mathrm{~mm}$ as a high antibiotic activity (+++). The antibiotic activity of each active extract was confirmed at least three times.

\section{RESULTS}

The extracts from seven benthic species did not show any antibiotic activity (Table 1). The extracts from the other 21 species showed different antibiotic potency among species and body sources utilized (Table 2).

In the phyla Porifera, Cnidaria, Sipucula, Annelida, Echinodermata and Chordata, the most of specimens analyzed as entire body showed a mild antibiotic activi- 
Table 1. Analysis of each benthic species collected as a source of antibiotic substances. *The antibiotic activity was assayed on the ethanol extract obtained from the entire organism or tissues from each organism studied, as described in material and methods.

\begin{tabular}{|c|c|c|c|}
\hline \multirow{3}{*}{ Phylum } & \multirow{3}{*}{ Class } & \multicolumn{2}{|c|}{ Benthic marine specie } \\
\hline & & \multicolumn{2}{|c|}{ Antibiotic activity* on Staphylococcus aureus } \\
\hline & & Negative & Positive \\
\hline Porifera & Desmospongiae & & Sponge sp. \\
\hline Cnidaria & Anthozoa & & $\begin{array}{l}\text { Anemonia alicemartinae } \\
\text { Anthothoe chilensis } \\
\text { Phymactis clematis } \\
\text { Phymanthea pluvia }\end{array}$ \\
\hline Mollusca & $\begin{array}{l}\text { Polyplacophora } \\
\text { Bivalvia } \\
\text { Gastropoda }\end{array}$ & $\begin{array}{l}\text { Collisella araucana } \\
\text { Thais chocolata }\end{array}$ & $\begin{array}{l}\text { Acanthopleura echinata } \\
\text { Chiton cumingsii } \\
\text { Aulacomya atra } \\
\text { Crepidula dilatata } \\
\text { Fissurella latimarginata } \\
\text { Fissurella crassa }\end{array}$ \\
\hline Sipuncula & Sipunculidea & & Themiste hennahi \\
\hline Annelida & Polychaeta & & $\begin{array}{l}\text { Abarenicola affinis } \\
\text { Glycera americana } \\
\text { Phragmatopoma moerchi }\end{array}$ \\
\hline Echinodermata & $\begin{array}{l}\text { Asteroidea } \\
\text { Echinoidea }\end{array}$ & $\begin{array}{l}\text { Heliaster helianthus } \\
\text { Patiria chilensis }\end{array}$ & $\begin{array}{l}\text { Luidia magellanica } \\
\text { Stichaster striatus } \\
\text { Arbacia spatuligera } \\
\text { Loxechinus albus }\end{array}$ \\
\hline & Holothuroidea & $\begin{array}{l}\text { Athyonidium chilensis } \\
\text { Patallus mollis }\end{array}$ & \\
\hline & Ophiuroidea & & Ophiactis kroyeri \\
\hline Chordata & Ascidiacea & Ascidiacea sp. & Pyura chilensis \\
\hline
\end{tabular}

ty, while Phymanthea pluvia (Cnidaria), Glycera americana (Annelida) and Ophiactis kroyeri (Echinodermata) showed a regular activity and Abarenicola affinis (Annelida) was the most active species (Table 2).

In Mollusca, only Crepidula dilatata showed tissues with mild antibiotic activity or no activity. Meanwhile, the other five species have diverse organs where were possible to obtain extracts with regular or high antibiotic activity. The digestive gland-intestine organ was the most frequent source with high activity, while lamellas, radular, periesophageal ring and feet showed a normal antibiotic activity (Table 2). Regarding the gonads as a source of antibiotic substances, the results showed variation among the species. In Aulacomya atra its gonads were a source of high and regular activity in female and males, respectively. In Chiton cumingsii, Fissurella latimarginata (male) and Fissurella crassa (male) their gonads were a source of regular antibiotic activity, while in Acanthopleura echinata, Fissurella latimarginata (female) and Fissurella crassa (female) their gonad's extracts did not show antibiotic activity. Other tissues that seem not to be a source of antibiotic substance, according to the methodology described was the retractor muscles of Aulacomya atra and the digestive gland-intestine in Crepidula dilatata (Table 2).

In the phylum Echinodermata, the species Arbacia spatuligera, Loxechinus albus and Luidia magellanica have external structure like arm dermoskeleton, central dermoskeleton, ambulacral feet and spines that were a good source of antibiotic substances with regular and high antibiotic activity, while in Stichaster striatus only the ambulacral feet was a source of regular antibiotic activity (Table 2). While intestine from A. spatuligera and $L$. albus were sources of substance with high antibiotic activity. In other internal organs like Aristoteles's lantern in A. spatuligera and L. albus, and stomach of $L$. magellanica the antibiotic activity extracted showed a regular potency (Table 2). Regarding the presence of antibiotic substances of gonads, the extracts obtained from gonads of female and male of $A$. spatuligera had high and regular antibiotic activity, respectively, while from gonads of $L$. albus, $L$. magellanica and $S$. striatus were inactive. 
Table 2. Antibiotic activity detected in the organic extract obtained from the entire body, organs, or structure of each marine organism studied.

\begin{tabular}{|c|c|c|c|c|c|}
\hline \multirow{2}{*}{ Phylum } & \multirow{2}{*}{ Species } & \multicolumn{4}{|c|}{ Antibiotic activity } \\
\hline & & Negative & Mild & Regular & High \\
\hline Porifera & Sponge sp. & & Entire body & & \\
\hline \multirow[t]{4}{*}{ Cnidaria } & Anemonia alicemartinae & & Entire body & & \\
\hline & Anthothoe chilensis & & Entire body & & \\
\hline & Phymactis clematis & & Entire body & & \\
\hline & Phymanthea pluvia & & & Entire body & \\
\hline \multirow[t]{6}{*}{ Mollusca } & Acanthopleura echinata & Gonad (female) & Ctenidia & $\begin{array}{l}\text { Periesophageal ring, foot, } \\
\text { radular }\end{array}$ & $\begin{array}{l}\text { Digestive gland- } \\
\text { intestine }\end{array}$ \\
\hline & Chiton cumingsii & & Radular & $\begin{array}{l}\text { Foot, gonad, digestive } \\
\text { gland-intestine }\end{array}$ & \\
\hline & Aulacomya atra & Retractor muscles & & $\begin{array}{l}\text { Mantle and gonad (male), } \\
\text { lamellas }\end{array}$ & $\begin{array}{l}\text { Mantle, gonad } \\
\text { (female), digestive } \\
\text { gland-intestine }\end{array}$ \\
\hline & Crepidula dilatata & $\begin{array}{l}\text { Gonads, digestive } \\
\text { gland-intestine }\end{array}$ & Foot & & \\
\hline & Fissurella latimarginata & Gonad (female) & & Gonad (male), foot & $\begin{array}{l}\text { Digestive gland- } \\
\text { intestine }\end{array}$ \\
\hline & Fissurella crassa & Gonad (female) & & Gonad (male), foot & $\begin{array}{l}\text { Digestive gland- } \\
\text { intestine }\end{array}$ \\
\hline Sipuncula & Themiste hennahi & & Entire body & & \\
\hline \multirow[t]{3}{*}{ Annelida } & Abarenicola affinis & & & & Entire body \\
\hline & Glycera americana & & & Entire body & \\
\hline & Phragmatopoma moerchi & & Entire body & & \\
\hline \multirow[t]{5}{*}{ Echinodermata } & Arbacia spatuligera & & & $\begin{array}{l}\text { Aristotles's lantern, gonad } \\
\text { (male) }\end{array}$ & $\begin{array}{l}\text { Intestine, gonad } \\
\text { (female), spines }\end{array}$ \\
\hline & Loxechinus albus & Gonads & & Aristotles's lantern, spines & Intestine \\
\hline & Luidia magellanica & Blind pyloric, gonad & & $\begin{array}{l}\text { Stomach, ambulacral feet, } \\
\text { central -dermoskeleton }\end{array}$ & Arm dermoskeleton \\
\hline & Stichaster striatus & $\begin{array}{l}\text { Stomach, blind pyloric, } \\
\text { central dermoskeleton, arm } \\
\text { dermoskeleton, gonad }\end{array}$ & & Ambulacral feet & \\
\hline & Ophiactis kroyeri & & & Entire body & \\
\hline Chordata & Pyura chilensis & & Entire body & & \\
\hline
\end{tabular}

\section{DISCUSSION}

In this study, 21 benthic species collected along the coast of the Tarapacá region produced antibiotic substances that were easily extracted with ethanol from diverse sources, showing different antibiotic potency. Regarding the seven benthic species negative for the antibiotic assay, they are members of classes Holothuroidea, Asteroidea, Gastropoda and Ascidiacea, which are known producer of a broad range of bioactive compounds with applications in medicine as antiangiogenic, anti-hypertension, anticoagulant, antitumor, antimicrobial, and other pharmacological applications (Rahman, 2014). Maybe, the lack of the antibiotic activity observed in this study was due to natural differences among species or because they produce apolar antibiotic substances not extracted with our methodology. The holothurian Athyonidium chilensis produce saponins that inhibit the growth of Staphylococcus aureus but were extracted with a different methodology using more apolar solvents like dichloromethane and methanol (Sottorff et al., 2013). Therefore, other extracted methodologies could be recommended to determine the presence of antibiotic substances in Chilean species of classes Holothuroidea, Asteroidea, Gastropoda and Ascidiacea.

Among the 21 benthic species identified as known producers of antibiotic substances, this is the first time that many of them are reported with this activity and correspond with similar studies in other members of the same class or phylum (Beattie et al., 2005; Dias et al., 2012; Suleria et al., 2015; Mariottini \& Grice, 2016; 
Nalini et al., 2018; Puglisi et al., 2019). A detail discussion distinguished by phylum follows.

\section{Porifera}

The phylum Porifera includes over 8,600 species distributed across different geographical locations making their comparison complex (Van Soest et al., 2012). There is a bacterial biofilm or microbiome associated with the sponge tissue that may synthesize pharmacological substances with application in infections disease and cancer (Laport et al., 2009; Indraningrat et al., 2016; Beesoo et al., 2017). Some of these microbiome bacteria have been isolated from sponge living in Valparaiso Bay at central Chile or Antarctic waters, showing a broad antimicrobial activity and anticancer properties as well (Papaleo et al., 2012; Henriquez-Camacho \& Losa, 2014; Claverias et al., 2015). Therefore, the antibiotic activity observed in the sponge species studied could come from the sponge itself or the associated microbiome. Hence, more research is recommended on these Chilean sponge species to identify the species and the sources of the antibiotic activity.

\section{Cnidarian}

Anemones and corals belong to the phylum Cnidaria, and many of them are the producer of peptides and organic compounds with the broad antimicrobial spectrum and extracted with organic solvents like ethanol (Retuerto et al., 2007; Mariottini \& Grice, 2016). For example, Stichodactyla mertensii and Stichodactyla gigantea produce antimicrobial compounds easily extracted with ethanol and capable of inhibiting the growth of gram-positive and gramnegative bacteria, and fungi (Thangaraj et al., 2011). Meanwhile, on the coast of Costa Rica, the ethanol extract from Anthopleura nigrescens showed antibiotic activity against several pathogens including Pseudomonas aeruginosa, Salmonella enterica, Escherichia coli, Proteus vulgaris and Klebsiella oxytoca (Borbón et al., 2016). Regarding the anemones, Phymanthea pluvia was the primary source of active antimicrobial extracts among the species studied, and this is described for the first time. In Phymactis clematis, the mild antimicrobial activity could be related to the hemolytic peptide Coelenterolysin, which has a similar motif with the antimicrobial peptides Magainin and Dermaseptin (Meinardi et al., 1994; Anderluh \& Macek, 2002). Meanwhile, for Anthothoe chilensis and Anemonia alicemartinae this is also the first report describing the antimicrobial activity. In this way, for Anthothoe chilensis in addition to the synthesis of highly lethal toxins (TX-1 and Anch TX-2) (Landucci et al., 2012), now can we add the synthesis of antibiotic substances that remains to identify.

\section{Mollusca}

In this phylum, some species belonging to Polyplacophora, Bivalvia and Gastropoda are known to produce diverse bioactive compounds having possible activity against virus infection (HIV), immune diseases and leukemia, smooth muscle contraction, or nicotine addiction (Hayashi et al., 1984; Benkendorff et al., 2005; Avila, 2015; Dang et al., 2015; Ciavatta et al., 2017). In this study, we found six molluscan species producers of antimicrobial substances; Acanthopleura echinata and Chiton cumingsii (Polyplacophora), Aulacomya atra (Bivalvia), and Crepidula dilatata, Fissurella latimarginata, and Fissurella crassa (Gastropoda). Their antibacterial activity was found in diverse organs, but the digestive gland-intestine tissue was the most active. In many marine species, including fish and invertebrates, the digestive gland-intestine tissue synthesizes antimicrobial peptides or enzymes as part of their immune response against infections (Smith et al., 2010). Hemocytes present in these organs can also be another source of antimicrobial peptides (Mitta et al., 2000).

In chitons, there are not many studies describing antimicrobial compounds (Bekendorf, 2010). Chitons shells harbor the polysaccharide chitin, which can absorb heavy metals and possess antimicrobial activity after alkali conversion in chitosan (Goy et al., 2009; Rasti et al., 2017; Roy et al., 2017). Chitin is insoluble in organic solvents (Roy et al., 2017), then maybe other compounds extracted from the foot, gonads and glandintestine could be related to the antibacterial activity observed in Chiton cumingsii.

In Bivalvia, only the mussel specie Aulacomya atra was studied. This specie lives along all Chilean coasts and in southern Atlantic. However, is curious that has been extensively studied as indicator of environmental pollution but not as an antibiotic producer (Tapia et al., 2010; Pozo et al., 2015; Ruiz et al., 2018), considering that mussel are natural filter that accumulated high quantities of microorganisms and therefore need of antimicrobial mechanisms to control its microbiome (Leoni et al., 2017; Rubiolo et al., 2019). In fact, in A. atra, high antibacterial activity was observed in its mantle, gonads, digestive gland and intestine. In other Bivalvia species, organs and the entire body have been described with antibacterial activity. In Perna viridis, methanol extract obtained from their gills, gastrointestinal tract and gonads were able of inhibiting the growth of Acinetobacter baumannii, Escherichia coli and Pseudomonas aeruginosa, and this activity were related with a protein of $9.7 \mathrm{kDa}$ (Chandran et al., 2009; Kiran et al., 2014). While in Perna erosa, Meretrix cast and Crassostrea gryphoides, their methanol extracts obtained from their entire body were shown to have a 
broad antibacterial and antifungal activity, and seems related with the secretion of antimicrobial peptides (Sharma et al., 2009). Therefore, considering all the literature above, there is a high possibility that the antibacterial activity observed in the Chilean mussel $A$. atra may be related to antimicrobial peptides. Hence, more studies have to be addressed to identify this or those antibiotic compounds.

Regarding marine snails (class Gastropoda), the high antibacterial activity observed in the digestive gland-intestine tissue of two Fissurella species might be related to hemocyanins. This protein is synthesized by different organs (Arancibia et al., 2014; Yao et al., 2019 ), and in $F$. latimarginata is a potent immunomodulator and antitumor molecule on mouse melanoma in comparison with hemocyanins extracted from other gastropods like Concholepas concholepas and Fissurella costata (Becker et al., 2012, 2014; Arancibia et al., 2014). Considering that antimicrobial peptides can be derived from hemocyanins (Zhuang et al., 2015), it would be interesting to study this protein in both Fissurella species.

\section{Sipuncula}

Themiste hennahi was the only member of the phylum Sipuncula studied. This report is describing for the first time a mild antibiotic activity in this species, but the chemical nature is still unknown. In similar species, a non-heme respiratory protein called hemerythrins (Alvarez-Carreño et al., 2016) plays a biological role in oxygen transport, iron and nitrogen metabolism, heavy metal detoxification and immunomodulation (Sheriff $e t$ al., 1987; Wittenberg, 1992; Vanin et al., 2006; Bailly et al., 2008; Stenkamp, 2011; Martín-Durán et al., 2013; Coates \& Decker, 2016; Alvarez-Carreño et al., 2018). However, we observed a direct antibiotic activity instead of an immunomodulatory role, suggesting the presence of other antibiotic substances different from hemerythrins in the analyzed organic extract. Therefore, more studies are encouraged on $T$. hennahi specie to identify the chemical nature of the extracted antimicrobial substances.

\section{Annelida}

This paper is the first report describing an antibiotic activity in the annelids species Abarenicola affinis, Glycera americana and Phragmatopoma moerchi. In close related species like Abarenicola pacifica and Arenicola marina, the synthesis of antimicrobial peptides with a broad antimicrobial spectrum has been reported (Tasiemski et al., 2007; Tasiemski, 2008; Lopez et al., 2014; Mariottini \& Grice, 2016; Vitali, 2018). In the genus Glycera, on the contrary, there is not much-related information, because this genus has been studied mainly as a producer of highly toxic neurotoxins that threaten human health rather than of antibiotics (Von Reumont et al., 2014). Only Glycera dibranchiata was reported as a source of a glycoprotein with a narrow antibiotic spectrum (Anderson \& Chain, 1982; Chain \& Anderson, 1983). Similarly, the genus Phragmatopoma is well known rather as a producer of adhesive molecules than of antibiotic molecules (Basiri et al., 2018); therefore, this is the first report describing an antibiotic production in one of its members.

\section{Echinodermata}

In the phylum Echinodermata, the analyzed species showed the same antibiotic activity than other Echinodermata species reported in the literature such as Strongylocentrotus droebachiensis, Asterias rubens, Cucumaria frondosa and Diadema setosum (Haug et al., 2011; Marimuthu et al., 2015). These extracts could contain antimicrobial peptides or saponins because both are easily extracted with organic solvents (Andersson et al., 1989; Li et al., 2008) and are produced by coelomocytes cells or tissue specific cells as part of their immune response against pathogens (Haug et al., 2011; Li et al., 2015; Coates et al., 2018; Nalini et al., 2018; Stabili et al., 2018). The coelomic cells of Loxechinus albus are reported as a producer of antibiotic substances activity against Escherichia coli (Pizarro et al., 2012), and this study is adding more sources of antibiotic substances in the same species. In the species Luidia magellanica, Stichaster striatus and Arbacia spatuligera, this is the first report in describing this antibiotic activity so far.

\section{Chordata}

In the phylum Chordata, only the ascidian species Pyura chilensis was analyzed, although many members of this taxonomic group are considered a natural sources of drugs to control depression, anxiety, infections and cancer (Kochanowska-Karamyan \& Hamann, 2010; Arumugam et al., 2018). This is the first report describing an antimicrobial activity in $P$. chilensis; considering the mild activity observed we suspect the presence of ferreascidin or something similar. Taking into account that ferreascidin is an ironchelating protein produced by Pyura stolonifera, a close specie to $P$. chilensis, and this iron affinity is a common characteristic found in other antimicrobial peptides like cionarin $\mathrm{H}$ and cianorin I produced by Ciona intestinalis (Dorsett et al., 1987; Doshi et al., 2011). More studies addressed to identify the chemical nature of the antibiotic compounds extracted and to relate this antibiotic activity with the iron metabolism are recommended. 


\section{CONCLUSIONS}

This study confirms the richness of Chilean benthic species as a producer of antimicrobial compounds. This property is described for the first time in many of them; being the opportunity to start new research on these benthic species and eventually discover new molecules with application in medicine is emphasized.

\section{ACKNOWLEDGMENTS}

The authors acknowledge the Vice-rectory of Research, Innovation and Post-grade of Arturo Prat University through their research grants VRIIP0220-15 and VRIIP0218-15. Also, the authors dedicated this report in the kindly memorial of Professor Raúl Soto-Mamani (2019), who enlightens the marine research of many students at Arturo Prat University. We also acknowledge the reviewer observations that significantly improved this manuscript.

\section{REFERENCES}

Aguilera, M.A., Aburto, J.A., Bravo, L., Broitman, B.R., García, R.A., Gaymer, C.F., Gelcich, S., López, B.A., Montecino, V., Pauchard, A., Ramos, M., Rutllant, J.A., Sáez, C.A., Valdivia, N., Thiel, M. \& Ramos, M. 2019. Chile: environmental status and future perspectives. In: Sheppard, C. (Ed.). World seas: an environmental evaluation. Academic Press, New York, pp. 673-702. doi: 10.1016/B978-0-12-8050682.00046-2

Alvarez-Carreño, C., Becerra, A. \& Lazcano, A. 2016. Molecular evolution of the oxygen-binding hemerythrin domain. Plos One, 11(6): 1-21. doi: 10.1371/journal. pone. 0157904

Alvarez-Carreño, C., Alva, V., Becerra, A. \& Lazcano, A. 2018. Structure, function, and evolution of the hemerythrin-like domain superfamily. Protein Science, 27(4): 848-860. doi:10.1002/pro.3374

Anderluh, G. \& Macek, P. 2002. Cytolytic peptide and protein toxins from sea anemones (Anthozoa: Actiniaria). Toxicon, 40(2): 111-124. doi:10.1016/ S0041-0101(01)00191-X

Anderson, R.S. \& Chain, B.M. 1982. Antibacterial activity in the coelomic fluid of a marine annelid, Glycera dibranchiata. Journal of Invertebrate Pathology, 40(3): 320-326. doi: 10.1016/0022-2011 (82)90170-7

Andersson, L., Bohlin, L., Iorizzi, M., Moreno-Lopez, W. \& Minale, L. 1989. Biological activity of saponins and saponin-like compounds from starfish and brittle-stars. Toxicon, 27(2): 179-188. doi: 10.1016/0041-0101 (89)90131-1
Arancibia, S., Espinoza, C., Salazar, F., Del Campo, M., Tampe, R., Zhong, T.Y., De Ioannes, P., Moltedo, B., Ferreira, J., Lavelle, E.C., Manubens, A., De Ioannes, A.E. \& Becker, M.I. 2014. A novel immunomodulatory hemocyanin from the limpet Fissurella latimarginata promotes potent anti-tumor activity in melanoma. Plos One, 9(1): e87240. doi: 10.1371/ journal.pone.0087240

Arnau, G.V., Danilovich, M.E., Sánchez, L.A., Acosta, F. \& Delgado, O. 2016. Biology and biotechnology of Patagonian microorganisms. In: Olivera, N., Libkind, D. \& Donati, E. (Eds.). Biology and biotechnology of Patagonian microorganisms. Springer, Berlin, pp. 127146. doi: 10.1007/978-3-319-42801-7

Arumugam, V., Venkatesan, M., Ramachandran, S. \& Sundaresan, U. 2018. Bioactive peptides from marine Ascidians and future drug development - a review. International Journal of Peptide Research and Therapeutics, 24(1): 13-18. doi: 10.1007/s10989-0179662-9

Avila, C. 2015. Molluscan natural products as biological models: chemical ecology, histology, and laboratory culture. In: Cimino, G. \& Gavagnin, M. (Eds.). Molluscs, from chemo-ecological study to biotechnological application. Springer, Berlin, pp. 1-23.

Bailly, X., Vanin, S., Chabasse, C., Mizuguchi, K. \& Vinogradov, S.N. 2008. A phylogenomic profile of hemerythrins, the nonheme diiron binding respiratory proteins. BMC Evolutionary Biology, 8(1): 1-11. doi: 10.1186/1471-2148-8-244

Basiri, Z., Rezayan, A.H., Akbari, B., Aghdam, R.M. \& Tafti, H.A. 2018. Developing new synthetic biomimetic nanocomposite adhesives: synthesis and evaluation of bond strength and solubilization. Reactive and Functional Polymers, 127(6): 85-93. doi: 10.1016/j.reactfunctpolym.2018.04.004

Beattie, A.J., Barthlott, W., Elisabetsky, E., Farrel, R., Kheng, C.T., Prance, I., Rosenthal, J., Simpson, D., Leakey, R., Wolfson, M. \& Laird, S. 2005. New products and industries from biodiversity. In: Hassan, R., Scholes, R. \& Ash, N. (Eds.). Ecosystems and human well-being: current state and trends, findings of the condition and trends working group. Island Press, Washington, pp. 273-295.

Becker, M.I., Arancibia, S., Salazar, F., Del Campo, M. \& De Ioannes, A. 2014. Mollusk hemocyanins as natural immunostimulants in biomedical applications. In: Thien, G. (Ed.). Immune response activation. IntechOpen Press, London, pp. 45-72. doi: 10.5772/ 57552

Becker, M.I., Arancibia, S., Cecilia, E., Salazar, F., Del Campo, M., Born, R., Ferreira, J., Manubens, A. \& De Ioannes, A. 2012. Novel hemocyanin from the Fissurella latimarginata exhibits outstanding immunogenicity and non-specific immunomodulatory effects 
in a melanoma model (53.6). Journal of Immunology, 188(1): 53-56.

Beesoo, R., Bhagooli, R., Neergheen-Bhujun, V.S., Li, W.W., Kagansky, A. \& Bahorun, T. 2017. Antibacterial and antibiotic potentiating activities of tropical marine sponge extracts. Comparative Biochemistry and Physiology Part C: Toxicology and Pharmacology, 196(6): 81-90. doi: 10.1016/j.cbpc.2017.04. 001

Benkendorff, K. 2010. Molluscan biological and chemical diversity: secondary metabolites and medicinal resources produced by marine mollusks. Biological Reviews, 85(4): 757-775. doi: 10.1111/j.1469-185X. 2010.00124.X

Benkendorff, K., Davis, A.R., Rogers, C.N. \& Bremner, J.B. 2005. Free fatty acids and sterols in the benthic spawn of aquatic molluscs, and their associated antimicrobial properties. Journal of Experimental Marine Biology and Ecology, 316(1): 29-44. doi: 10.1016/j.jembe.2004.10.001

Betti, F., Bavestrello, G., Bo, M., Enrichetti, F., Loi, A., Wanderlingh, A., Pérez-Santos, I. \& Daneri, G. 2017. Benthic biodiversity and ecological gradients in the Seno Magdalena (Puyuhuapi Fjord, Chile). Estuarine, Coastal and Shelf Science, 198: 269-278. doi: 10.1016/j.ecss.2017.09.018

Borbón, H., Váldes, S., Alvarado-Mesén, J., Soto, R. \& Vega, I. 2016. Antimicrobial properties of sea anemone Anthopleura nigrescens from the Pacific coast of Costa Rica. Asian Pacific Journal of Tropical Biomedicine, 6(5): 418-421. doi: 10.1016/j.apjtb. 2016.01.014

Campos, P.E., Pichon, E., Moriou, C., Clerc, P., Trépos, R., Frederich, M., De Voogd, N., Hellio, C., GauvinBialecki, A. \& Al-Mourabit, A. 2019. New antimalarial and antimicrobial tryptamine derivatives from the marine sponge Fascaplysinopsis reticulata. Marine Drugs, 17(3): 167. doi: 10.3390/md17030167

Castilla, J.C. \& Fernandez, M. 1998. Small-scale benthic fisheries in Chile: on co-management and sustainable use of benthic invertebrates. Ecological Applications, 8(1): 124-132. doi: 10.1890/1051-0761(1998)8[S124: SBFICO]2.0.CO;2

Chain, B.M. \& Anderson, R.S. 1983. Antibacterial activity of the coelomic fluid from the polychaete, Glycera dibranchiata. Partial purification and biochemical characterization of the active factor. Biological Bulletin, 164(1): 41-49. doi: 10.2307/1541188

Chandran, B., Rameshkumar, G. \& Ravichandran, S. 2009. Antimicrobial activity from the gill extraction of Perna viridis (Linnaeus, 1758). Global Journal of Biotechnology and Biochemistry Research, 4(2): 8892.

Ciavatta, M.L., Lefranc, F., Carbone, M., Mollo, E., Gavagnin, M., Betancourt, T., Dasari, R., Kornienko,
A. \& Kiss, R. 2017. Marine mollusk-derived agents with antiproliferative activity as promising anticancer agents to overcome chemotherapy resistance. Medicinal Research Reviews, 37(4): 702-801. doi: 10.1002/med.21423

Claverías, F.P., Undabarrena, A., González, M., Seeger, M. \& Cámara, B. 2015. Culturable diversity and antimicrobial activity of actinobacteria from marine sediments in Valparaíso bay, Chile. Frontiers in Microbiology, 6: 1-11. doi: 10.3389/fmicb.2015.00 737

Coates, C.J. \& Decker, H. 2016. Immunological properties of oxygen-transport proteins: hemoglobin, hemocyanin, and hemerythrin. Cellular and Molecular Life Sciences, 74(2): 293-317. doi: 10.1007/s00018016-2326-7

Coates, C.J., McCulloch, C., Betts, J. \& Whalley, T. 2018. Echinochrome, a release by red spherule cells, is an iron-withholding strategy of sea urchin innate immunity. Journal of Innate Immunity, 10(2): 119130. doi: $10.1159 / 000484722$

Dang, V.T., Benkendorff, K., Green, T. \& Speck, P. 2015. Marine snails and slugs: a great place to look for antiviral drugs: table 1. Journal of Virology, 89(16): 8114-8118. doi: 10.1128/JVI.00287-15

Dias, D.A., Urban, S. \& Roessner, U. 2012. A historical overview of natural products in drug discovery. Metabolites, 2(2): 303-336. doi: 10.3390/metabo2020 303

Dorsett, L.C., Hawkins, C.J., Grice, J.A., Merefield, P.M., Parry, D.L., Ross, I.L. \& Lavin, M.F. 1987. Ferreascidin: a highly aromatic protein-containing 3,4dihydroxyphenylalanine from the blood cells of a stolidobranch ascidian. Biochemistry, 26(25): 80788082. doi: 10.1021/bi00399a009

Doshi, G.M., Aggarwal, G.V, Martis, E.A. \& Shanbhag, P.P. 2011. Novel antibiotics from marine sources. International Journal of Pharmaceutical Sciences and Nanotechnology, 4(3): 1446-1461.

El Chakhtoura, N.G., Saade, E., Iovleva, A., Yasmin, M., Wilson, B., Perez, F. \& Bonomo, R.A. 2018. Therapies for multidrug-resistant and extensively drug-resistant non-fermenting gram-negative bacteria causing nosocomial infections: a perilous journey toward 'molecularly targeted' therapy. Expert Review of Anti-Infective Therapy, 16(2): 89-110. doi: 10.1080/ 14787210.2018.1425139

Escribano, R., Fernández, M. \& Aranís, A. 2003. Physical-chemical processes and patterns of diversity of the Chilean eastern boundary pelagic and benthic marine ecosystems: an overview. Gayana, 67(2): 190205. doi: $10.4067 /$ S0717-65382003000200008

Gallardo, V.A., Carrasco, F.D., Roa, R. \& Cañete, J.I. 1995. Ecological patterns in the benthic macrobiota across the continental shelf off central Chile. Ophelia, 
40(3): 167-188. doi: 10.1080/00785326.1995.10430 583

Goy, R.C., Britto, D. \& De Assis, O.B.G. 2009. A review of the antimicrobial activity of chitosan. Polímeros: Ciência e Tecnologia, 19(3): 241-247. doi: 10.1093/ jac/dkg286

Haug, T., Kjuul, A.K., Styrvold, O.B., Sandsdalen, E., Olsen, Ø.M. \& Stensvag, K. 2011. Antibacterial activity in Strongylocentrotus droebachiensis (Echinoidea), Cucumaria frondosa (Holothuroidea), and Asterias rubens (Asteroidea). Journal of Invertebrate Pathology, 81(1): 94-102. doi: 10.1016/ S0022-2011(02)00153-2

Hayashi, E., Isogai, M., Kagawa, Y., Takayanagi, N. \& Yamada, S. 1984. Neosurugatoxin, a specific antagonist of nicotinic acetylcholine receptors. Journal of Neurochemistry, 42(5): 1491-1494. doi: 10.1111/j.14 71-4159.1984.tb02817.x

Hayashida-Soiza, G., Uchida, A., Mori, N., Kuwahara, Y. \& Ishida, Y. 2008. Purification and characterization of antibacterial substances produced by a marine bacterium Pseudoalteromonas haloplanktis strain. Journal of Applied Microbiology, 105(5): 1672-1677. doi: 10.1111/j.1365-2672.2008.03878.x

Henriquez, P., Candia, A., Norambuena, R., Silva, M. \& Zemelman, R. 1979. Antibiotic properties of marine algae. Screening of Chilean marine algae for antimicrobial activity. Botanica Marina, 22(7): 451-454. doi: 10.1515/botm.1979.22.7.451

Henriquez-Camacho, C. \& Losa, J. 2014. Biomarkers for sepsis. BioMed Research International, 2014: 547818. doi: $10.1155 / 2014 / 547818$

Indraningrat, A.A.G., Smidt, H. \& Sipkema, D. 2016. Bioprospecting sponge-associated microbes for antimicrobial compounds. Marine Drugs, 14(5): 1-66. doi: $10.3390 / \mathrm{md} 14050087$

Isler, B., Doi, Y., Bonomo, R.A. \& Paterson, D.L. 2019. New treatment options against carbapenem-resistant Acinetobacter baumannii infections. Antimicrobial Agents and Chemotherapy, 63(1): e01110-18. doi:10. 1128/AAC.01110-18

Jiménez, E., Dorta, F., Medina, C., Ramírez, A., Ramírez, I. \& Peña-Cortés, H. 2011. Anti-phytopathogenic activities of macro-algae extracts. Marine Drugs, 9(5): 739-756. doi: 10.3390/md9050739

Kiran, N., Siddiqui, G., Khan, A.N., Ibrar, K. \& Tushar, P. 2014. Extraction and screening of bioactive compounds with antimicrobial properties from selected species of mollusk and crustacean. Journal of Clinical and Cellular Immunology, 5: 1-5.

Kochanowska-Karamyan, A.J. \& Hamann, M.T. 2010. Marine indole alkaloids: potential new drug leads for the control of depression and anxiety. Chemical Reviews, 110(8): 4489-4497. doi:10.1021/cr900211p
Landucci, E.C.T., Dias, Q.C., Marangoni, F.A., VilcaQuispe, A., Valeriano-Zapana, J.A., Torres-Huaco, F.D., Martins-de-Souza, D., Marangoni, S. \& PonceSoto, L.A. 2012. Purification and inflammatory edema induced by two PLA2 (Anch TX-I and Anch TX-II) from sea anemone Anthothoe chilensis (Actiniaria: Sagartiidae). Comparative Biochemistry and Physiology Part B: Biochemistry and Molecular Biology, 161(2): 170-177. doi: 10.1016/j.cbpb.2011.11.003

Laport, M.S., Santos, O.C.S. \& Muricy, G. 2009. Marine sponges: potential sources of new antimicrobial drugs. Current Pharmaceutical Biotechnology, 10(1): 86-105. doi: 10.2174/138920109787048625

Lee, M.R., Castilla, J.C., Fernández, M., Clarke, M., González, C., Hermosilla, C., Prado, L., Rozbaczylo, N. \& Valdovinos, C. 2008. Free-living benthic marine invertebrates in Chile. Revista Chilena de Historia Natural, 81(1): 51-67. doi: 10.4067/S0716-078X2008 000100005

Leoni, G., De Poli, A., Mardirossian, M., Gambato, S., Florian, F., Venier, P., Wilson, D.N., Tossi, A., Pallavicini, A. \& Gerdol, M. 2017. Myticalins: a novel multigenic family of linear, cationic antimicrobial peptides from marine mussels (Mytilus spp.). Marine Drugs, 15(8): 261. doi: 10.3390/md15080261

Li, C., Blencke, H.M., Haug, T. \& Stensvåg, K. 2015. Antimicrobial peptides in echinoderm host defense. Developmental and Comparative Immunology, 49(1): 190-197. doi: 10.1016/j.dci.2014.11.002

Li, C., Haug, T., Styrvold, O.B., Jørgensen, T.Ø. \& Stensvåg, K. 2008. Strongylocins, novel antimicrobial peptides from the green sea urchin, Strongylocentrotus droebachiensis. Developmental \& Comparative Immunology, 32(12): 1430-1440. doi: 10.1016/j.dci. 2008.06.013

Lopez, Y., Cepas, V. \& Soto, S.M. 2014. The marine ecosystem as a source of antibiotics. In: Rampelotto, P.H. \& Trincone, A. (Eds.). Grand challenges in marine biogeochemistry. Springer, Cham, pp. 3-48.

Marimuthu, K., Gunaselvam, P., Rahman, M.A., Xavier, R., Arockiaraj, J., Subramanian, S., Yusoff, F.M.A. \& Arshad, A. 2015. Antibacterial activity of ovary extract from sea urchin Diadema setosum. European Review for Medical and Pharmacological Sciences, 19(6): 1895-1899.

Mariottini, G.L. \& Grice, I.D. 2016. Antimicrobials from Cnidarians. A new perspective for anti-infective therapy? Marine Drugs, 14(3): 1-19. doi: 10.3390/md 14030048

Martín-Durán, J.M., De Mendoza, A., Sebé-Pedrós, A., Ruiz-Trillo, I. \& Hejnol, A. 2013. A broad genomic survey reveals multiple origins and frequent losses in the evolution of respiratory hemerythrins and hemo- 
cyanins. Genome Biology and Evolution, 5(7): 14351442. doi: $10.1093 /$ gbe/evt 102

Meinardi, E., Azcurra, J.M., Florin-Christensen, M. \& Florin-Christensen, J. 1994. Coelenterolysin: a hemolytic polypeptide associated with the coelenteric fluid of sea anemones. Comparative Biochemistry and Physiology Part B: Biochemistry and Molecular Biology, 109(1): 153-161. doi: 10.1016/0305-0491 (94) $90152-X$

Mercado, G., Tello, M., Marín, M., Monasterio, O. \& Lagos, R. 2008. The production in vivo of microcin E492 with antibacterial activity depends on salmochelin and EntF. Journal of Bacteriology, 190(15): 5464-5471. doi: 10.1128/JB.00351-08

Mitta, G., Vandenbulcke, F. \& Roch, P. 2000. Original involvement of antimicrobial peptides in mussel innate immunity. FEBS Letters, 486(3): 185-190. doi: 10.1016/s0014-5793(00) 02192-х

Nalini, S., Sandy-Richard, D., Mohammed-Riyaz, S.U., Kavitha, G. \& Inbakandan, D. 2018. Antibacterial macromolecules from marine organisms. International Journal of Biological Macromolecules, 115(8): 696710. doi: 10.1016/j.ijbiomac.2018.04.110

Ogawa, V.A., Shah, C.M., Hughes, J.M. \& King, L.J. 2018. Prioritizing a one health approach in the immediate fight against antimicrobial resistance. EcoHealth, 9(3): 1-4. doi: 10.1007/s10393-018-13256

Papaleo, M.C., Fondi, M., Maida, I., Perrin, E., Giudice, A.L., Michaud, L., Mangano, S., Bartolucci, G., Romoli, R.F. \& Fani, R. 2012. Sponge-associated microbial Antarctic communities exhibiting antimicrobial activity against Burkholderia cepacia complex bacteria. Biotechnology Advances, 30(1): 272-293. doi: 10.1016/j.biotechadv.2011.06.011

Pansch, C., Cerda, O., Lenz, M., Wahl, M. \& Thiel, M. 2009. Consequences of light reduction for antiherbivore defense and bioactivity against mussels in four seaweed species from northern-central Chile. Marine Ecology Progress Series, 381(4): 83-97. doi: 10.3354/meps07943

Pizarro, F., Parra-Lepe, M. \& Astorga, D. 2012. Estudio y comparación de la actividad antibacteriana de dos erizos de mar, Loxechinus albus y Tetrapygus niger, frente a Escherichia coli. Revista Ciencia Joven, e20. doi: 10.7578/cienciajoven.201212

Pozo, K., Kukučka, P., Vaňková, L., Přibylová, P., Klánová, J., Rudolph, A., Banguera, Y., Monsalves, J., Contreras, S., Barra, R. \& Ahumada, R. 2015. Polybrominated diphenyl ethers (PBDEs) in Concepción Bay, central Chile after the 2010 Tsunami. Marine Pollution Bulletin, 95(1): 480-483. doi: 10.1016/j. marpolbul.2015.03.011

Prakash, B., Kujur, A. \& Yadav, A. 2018. Drug synthesis from natural products: a historical overview and future perspective. In: Tewari, A. \& Tiwari, S. (Eds.). Synthesis of medicinal agents from plants. Elsevier, Amsterdam, pp. 25-46. doi: 10.1016/B978-0-08102071-5/00002-7

Puglisi, M.P., Sneed, J.M., Ritson-Williams, R. \& Young, R. 2019. Marine chemical ecology in benthic environments. Natural Product Reports, 36(3): 410429. doi: 10.1039/C8NP00061A

Rahman, M.A. 2014. Global sea cucumber fisheries: their culture potentials, bioactive compounds and sustainable utilizations. International Journal of Advances in Chemical Engineering and Biological Sciences, 1(2): 193-197. doi: 10.15242/ijacebs.a111 4056

Rasti, H., Parivar, K., Baharara, J., Iranshahi, M. \& Namvar, F. 2017. Chitin from the mollusk chiton: extraction, characterization, and chitosan preparation. Iranian Journal of Pharmaceutical Research, 16(1): 366-379. doi: 10.3390/ijms17121976

Retuerto, F., Arbaiza, E., Quiroz-Garrido, Y., Estrada, R. \& Zavala, J. 2007. Actividad biológica del veneno de Anthothoe chilensis (Lesson, 1830) (Actiniaria: Sagartiidae). Revista Peruana de Biología, 14(2): 277-282. doi: 10.15381/rpb.v14i2.1800

Roy, J.C., Salaün, F., Giraud, S., Ferri, A., Chen, G. \& Guan, J. 2017. Solubility of chitin: solvents, solution behaviors, and their related mechanisms. In: $\mathrm{Xu}, \mathrm{Z}$. (Ed.). Solubility of polysaccharides. TechOpen Press, Vienna, pp. 109-127.

Rubiolo, J.A., Botana, L.M. \& Martínez, P. 2019. Insights into mussel microbiome. In: Derome, N. (Ed.). Microbial Communities in Aquaculture Ecosystems. Springer, Cham, pp. 95-120. doi: 10.1007/978-3-03016190-3_5

Ruiz, M.D., Iriel, A., Yusseppone, M.S., Ortiz, N., Di Salvatore, P., Cirelli, A.F., Ríos de Molina-Calcagno, M.C.J.A. \& Sabatini, S.E. 2018. Trace metals and oxidative status in soft tissues of caged mussels (Aulacomya atra) on the north Patagonian coastline. Ecotoxicology and Environmental Safety, 155(7): 152-161. doi: 10.1016/j.ecoenv.2018.02.064

Sana, F., Satti, L., Zaman, G., Gardezi, A., Imtiaz, A., Ahmed, A. \& Khadim, M.T. 2017. Pattern of Gramnegative bloodstream infections and their antibiotic susceptibility profiles in a neonatal intensive care unit. Journal of Hospital Infection, 98(3): 243-244. doi: 10.1016/j.jhin. 2017.10.024

San-Martin, A., Rovirosa, J., Vaca, I., Vergara, K., Acevedo, L., Vina, D., Orallo, F. \& Chamy, M.C. 2011. New butyrolactone from a marine-derived fungus Aspergillus sp. Journal of the Chilean Chemical Society, 56(1): 625-627. doi: 10.4067/ S0717-97072011000100023

Sharma, S., Chatterji, A. \& Das, P. 2009. Effect of different extraction procedures on antimicrobial activity of 
marine bivalves: a comparison. Pertanika Journal of Tropical Agricultural Science, 32(1): 77-83.

Sheriff, S., Hendrickson, W.A. \& Smith, J.L. 1987. Structure of myohemerythrin in the azidomet state at 1.7/1.3. A resolution. Journal of Molecular Biology, 197(2): 273-296. doi: 10.1016/0022-2836(87)90124-0

Smith, V.J., Desbois, A.P. \& Dyrynda, E.A. 2010. Conventional and unconventional antimicrobials from fish, marine invertebrates, and micro-algae. Marine Drugs, 8(4): 1213-1262. doi: 10.3390/md8041213.

Sottorff, I., Aballay, A., Hernández, V., Roa, L., Muñoz, L.X., Silva, M., Becerra, J. \& Astuya, A. 2013. Characterization of bioactive molecules isolated from sea cucumber Athyonidium chilensis. Revista de Biología Marina y Oceanografía, 48(1): 23-35. doi: 10.4067/S0718-19572013000100003

Stabili, L., Acquaviva, M.I., Cavallo, R.A., Gerardi, C., Narracci, M. \& Pagliara, P. 2018. Screening of three echinoderm species as new opportunity for drug discover: their bioactivities and antimicrobial properties. Evidence-Based Complementary and Alternative Medicine, 2018: e7891748. doi: 10.1155/ 2018/7891748

Stenkamp, R.E. 2011. Hemerythrin. In: Scott, R.A. (Ed.). Encyclopedia of inorganic and bioinorganic chemistry. John Wiley \& Sons Press, New York, pp. 1-13. doi: 10.1002/9781119951438.eibc0577

Suleria, H.A.R., Osborne, S., Masci, P. \& Gobe, G. 2015. Marine-based nutraceuticals: an innovative trend in the food and supplement industries. Marine Drugs, 13(10): 6336-6351. doi: 10.3390/md13106336

Tapia, J., Vargas-Chacoff, L., Bertrán, C., Carrasco, G., Torres, F., Pinto, R., Urzúa, S., Valderrama, A. \& Letelier, L. 2010. Study of the content of cadmium, chromium and lead in bivalve mollusks of the Pacific Ocean (Maule Region, Chile). Food Chemistry, 121(3): 666-671. doi: 10.1016/j.foodchem.2009.12. 091

Tasiemski, A. 2008. Antimicrobial peptides in annelids. Invertebrate Survival Journal, 5(1): 75-82.

Tasiemski, A., Schikorski, D., Le Marrec-Croq, F., Pontoire-Van Camp, C., Boidin-Wichlacz, C. \& Sautière, P.E. 2007. Hedistin: a novel antimicrobial peptide containing bromotryptophan constitutively expressed in the NK cells-like of the marine annelid, Nereis diversicolor. Developmental and Comparative Immunology, 31(8): 749-762. doi: 10.1016/j.dci.2006. 11.003

Thangaraj, S., Bragadeeswaran, S., Suganthi, K. \& Sri Kumaran, N. 2011. Antimicrobial properties of sea anemone Stichodactyla mertensii and Stichodactyla gigantea from Mandapam coast of India. Asian Pacific Journal of Tropical Biomedicine, 1(1): 43-46. doi: 10.1016/S2221-1691(11)60120-2

Undabarrena, A., Beltrametti, F., Claverías, F.P., González, M., Moore, E.R.B., Seeger, M. \& Cámara, B. 2016. Exploring the diversity and antimicrobial potential of marine actinobacteria from the Comau Fjord in northern Patagonia, Chile. Frontiers in Microbiology, 7: 1-16. doi: 10.3389/fmicb.2016.011 35

Vanin, S., Negrisolo, E., Bailly, X., Bubacco, L., Beltramini, M. \& Salvato, B. 2006. Molecular evolution and phylogeny of sipunculan hemerythrins. Journal of Molecular Evolution, 62(1): 32-41. doi: 10.1007/s00239-004-0296-0

Van Soest, R.W.M., Boury-Esnault, N., Vacelet, J., Dohrmann, M., Erpenbeck, D., De Voogd, N.J., Santodomingo, N., Vanhoorne, B., Kelly, M. \& Hooper J.N.A. 2012. Global diversity of sponges (Porifera). Plos One, 7(4): e35105. doi: 10.1371/journal.pone. 0035105

Vitali, A. 2018. Antimicrobial peptides derived from marine sponges. American Journal of Clinical Microbiology and Antimicrobials, 1(1): 1006.

Von Reumont, B.M., Campbell, L.I., Richter, S., Hering, L., Sykes, D., Hetmank, J. \& Bleidorn, C. 2014. A polychaete's powerful punch: venom gland transcriptomics of Glycera reveals a complex cocktail of toxin homologs. Genome Biology and Evolution, 6(9): 2406-2423. doi: 10.1093/gbe/evu190

Wagenlehner, F., Tandogdu, Z., Bartoletti, R., Cai, T., Cek, M., Kulchavenya, E., Köves, B., Naber, K., Perepanova, T., Tenke, P., Wullt, B., Bogenhard, F. \& Johansen, T. 2016. The global prevalence of infections in urology study: a long-term, worldwide surveillance study on urological infections. Pathogens, 5(1): 10. doi: 10.3390/pathogens5010010

Wittenberg, J.B. 1992. Functions of cytoplasmic hemoglobins and myohemerythrin. In: Mangum, Ch.P. (Ed.). Blood and tissue oxygen carriers. Advances in Comparative and Environmental Physiology. Springer, Berlin, pp: 59-85.

Yao, T., Zhao, M.M., He, J., Han, T., Peng, W., Zhang, H., Wang, J.Y. \& Jiang, J.Z. 2019. Gene expression and phenoloxidase activities of hemocyanin isoforms in response to pathogen infections in abalone Haliotis diversicolor. International Journal Biological Macromolecules, 129: 538-551. doi: 10.1016/j.ijbiomac. 2019.02.013.

Zhuang, J., Coates, C.J., Zhu, H., Zhu, P., Wu, Z. \& Xie, L. 2015. Identification of candidate antimicrobial peptides derived from abalone hemocyanin. Developmental \& Comparative Immunology, 49(1): 96-102. doi: 10.1016/j.dci.2014.11.008 